\title{
Shedding a Light on the Human Rights of Small-scale Fishers: Complementarities and Contrasts between the UN Declaration on Peasants' Rights and the Small-Scale Fisheries Guidelines ${ }^{1}$
}

Elisa Morgera

Director of the UKRI GCRF One Ocean Hub (OOH), University of Strathclyde Law School, Lord Hope Building, 141 St James Road, Glasgow G4 OLT, UK; https://oneoceanhub.org. Professor of Global Environmental Law at Strathclyde Centre for Environmental Law and Governance (SCELG), University of Strathclyde Law School, Lord Hope Building, 141 St James Road, Glasgow G4 OLT, UK; elisa.morgera@strath.ac.uk. https://orcid.org/0000-0002-5234-8784

Julia Nakamura

PhD Candidate at Strathclyde Centre for Environmental Law and Governance (SCELG), University of Strathclyde Law School, Lord Hope Building, 141 St James Road, Glasgow G4 OLT, UK; julia.nakamura@strath.ac.uk.https://orcid.org/0000-0002-2558-1732

\begin{abstract}
The UN Declaration on Peasants' Rights (UNDROP) underscores the need for a coherent interpretation and application of existing international human rights to the specific context of small-scale fisheries (SSF), including small-scale marine and continental capture fishing, small-scale aquaculture, related preparatory works and cultural practices. It complements the UN Food and Agriculture Organization (FAO)'s Voluntary Guidelines for Securing Sustainable Small-Scale Fisheries in the context of food security and poverty eradication (SSF Guidelines), which were the first international instrument entirely dedicated to SSF. The two instruments originate from forums that frame issues and respective responses differently, involving individuals and specialised international bodies with distinct interests and areas of expertise (human rights and fisheries, respectively), and having garnered differing levels of intergovernmental support. The two instruments thus offer their own particular perspectives on how international law currently relates to the challenges and contributions of SSF. Against this backdrop, this Chapter will analyse and compare the contributions of the UNDROP and the SSF Guidelines to the recognition, protection, respect and full realisation of the human rights of peasants involved in SSF and to the sustainable use of natural resources in SSF, with a view to supporting the relevant Sustainable Development Goals (SDGs).
\end{abstract}

Keywords

UN Declaration on Peasants' Rights - Small-Scale Fisheries Guidelines - human rights -Sustainable Development Goals

\footnotetext{
The authors are thankful to Margherita Brunori, Jackie Sunde, Bernadette Snow, Lorenzo Cotula, Patrick Vrencken, and Ana Suarez Dussan for their valuable comments and inputs to an earlier version of this chapter. This chapter has been prepared under the UKRI GCRF One Ocean Hub (The One Ocean Hub is a collaborative research for sustainable development project funded by UK Research and Innovation (UKRI) through the Global Challenges Research Fund (GCRF) (Grant Ref: NE/S008950/1). GCRF is a key component in delivering the UK AID strategy and puts UK-led research at the heart of efforts to tackle the United Nations Sustainable Development Goals.
} 


\section{Introduction}

The UN Declaration on Peasants' Rights (UNDROP or Declaration) ${ }^{2}$ expressly covers any person, including indigenous peoples and local communities, engaged in artisanal or small-scale fishing and related handicrafts in rural areas. ${ }^{3}$ There is nodoubt, therefore, that the Declaration applies to small-scale fisheries (SSF) and affirms their human rights. It embodies the recognition ${ }^{4}$ of the need for a coherent interpretation and application of existing international human rights standards to a broad range of actors involved in small-scale fishing, ${ }^{5}$ to ensure their full enjoyment of all human rights. ${ }^{6}$ It also represents the commitment of States to promptly take steps to enhance the protection of all rights spelled out therein. ${ }^{7}$

Before the adoption of the UNDROP, the UN Food and Agriculture Organization (FAO)'s Voluntary Guidelines for Securing Sustainable Small-Scale Fisheries in the context of food security and poverty eradication (SSF Guidelines) ${ }^{8}$ was the only international instrument specially dedicated to small-scale fisheries and making express references to fishers' rights. The SSF Guidelines were developed as part of FAO's long-standing efforts to contribute to the coherent interpretation and application of international instruments on sustainable fisheries, at the crossroads of international fisheries law and international environmental law. ${ }^{9}$ International human rights law has also informed and been incorporated in the SSF Guidelines, which offer specific guidance on States' obligation in respect to the rights of women, ${ }^{10}$ indigenous peoples, ${ }^{11}$ migrants ${ }^{12}$ and children. ${ }^{13}$

2 United Nations Declaration on the Rights of Peasants and Other People Working in Rural Areas, UNGA Resolution A/C.3/73/L.30 (28 September 2018) (adopted by 33 votes to 3; 11 abstentions) (UNDROP).

ibid, art. 1(2)(3).

4 The UNDROP was adopted by majority voting at the UN General Assembly and at the Human Rights Council, as discussed in section below on the development of the UNDROP and the SSF Guidelines.

5 To name a few: right to access to and sustainable use of natural resources (art. 5(1)), right to life (art. 6(1)), right to freedom of thought, belief, conscience, religion, opinion, expression and peaceful assembly (art. 8(1)), right to active and free participation in preparation and implementation of policies (art. 10(1)), right to effective and nondiscriminatory access to justice (art. 12(1)), etc.

6 ibid, art. 3(1).

ibid, art. 2(1).

8 Voluntary Guidelines for Securing Sustainable Small-scale fisheries in the context of food security and poverty eradication (adopted at the 31st Session of the Committee on Fisheries, 9-13 June 2014) 18p.

9 Code of Conduct for Responsible Fisheries (adopted 31 October 1995, Resolution 4/95 FAO Conference).

10 In reference to women throughout many parts of the SSF Guidelines, as will be detailed later, and specifically to the Convention on the Elimination of All Forms of Discrimination against Women (Adopted 18 December 1979, entered into force 3 September 1981) 1249 UNTS 13 (CEDAW).

11 In reference to indigenous peoples in many parts of the SSF Guidelines, as will also be detailed later and specifically to the United Nations Declaration on the Rights of Indigenous Peoples, UNGA Res 61/295 (13 September 2007) (adopted by 144 votes to $4 ; 11$ abstentions).

12 In reference to migrants in SSF. No specific international instrument dedicated to migrant workers is mentioned in the SSF Guidelines, which generally refers to relevant ILO instruments. These may include the Work in Fishing Convention (Adopted 14 June 2007, entered into force 16 November 2017) (C188); and the Migration for Employment Convention (Revised) (Adopted 01 July 1949, entered into force 22 January 1952) (C097).

13 In reference to children engaged in SSF and, in specific, to the Convention on the Rights of the Child (Adopted 20 November 1989, entered into force 2 September 1990) 1577 UNTS 3 (CRC). 
Notwithstanding the importance of the SSF Guidelines, very little has been said about this instrument and its application in the context of the UNDROP. Originating from forums that frame issues and respective responses differently, and which involve individuals and specialised international bodies with distinct interests and areas of expertise $^{14}$ (human rights and fisheries, respectively), ${ }^{15}$ these two instruments offer their own particular perspectives on how international law currently addresses the challenges and contributions of SSF to overall sustainable fisheries. This Chapter explores the extent to which they can and should be read together, with a view to illuminate a mutually supportive ${ }^{16}$ interpretation of multiple - and traditionally disconnected - sources of international law, all of which applies to SSF. To that end, this Chapter will analyse and compare the two instruments with respect to the processes that have led to their development and adoption; the notion of SSF and their scope of application; the recognition and protection of customary tenure of fishery resources, the protection of small-scale fishers' traditional knowledge, and the relevance of procedural rights. These findings are then brought together to demonstrate how the mutually supportive interpretation of the two instruments can support States in the realization of multiple Sustainable Development Goals (SDGs), which include targets on providing access of small-scale fishers to land, marine resources, productive resources and inputs, knowledge, financial services, markets and opportunities for value addition. ${ }^{17}$

\section{The development of the UNDROP and the SSF Guidelines}

The making and adoption of the UNDROP and the SSF Guidelines provide concrete examples of participatory international law-making processes led by distinct international UN bodies with different mandates, ${ }^{18}$ memberships and processes. The UNDROP was the result of long-standing efforts driven by international agrarian

14 That is expertise from a range of actors, from the government-level to the community-level. Both the UNDROP and the SSF Guidelines, as detailed further below, were the outcomes of participatory processes, proving possible to obtain participation by non-State actors, notably small-scale fishers' representatives, in processes that have been traditionally technocratic and States-driven.

15 While fisheries management has been traditionally the focus of international fisheries instruments, modern international fisheries law (to which FAO is inherently associated with as being the main UN agency driving the legal developments of this domain) has been changing in the past decades to encompass environmental and social concerns in fisheries. For a comprehensive collection that brought about various aspects of this evolving international law field, which draws attention to environmental considerations and evolution in international fisheries law, see E. J. Molenaar and R. Caddell, Strengthening International Fisheries Law in an Era of Changing Oceans (Hart Publishing 2019). For linkages between international fisheries law and the protection of people at sea, including fishers, see I. Papanicolopulu, International Law and the Protection of People at Sea (Oxford University Press 2018).

16 That is, 'mutual supportiveness' among different international regimes to be 'understood and applied as reinforcing each other with a view to fostering harmonization and complementarity, as opposed to conflictual relationships', as argued in R. Pavoni, 'Mutual Supportiveness as a Principle of Interpretation and Law-Making: A Watershed for the 'WTO-and-Competing-Regimes’ Debate?' (2010) 21 European Journal of International Law 649.

17 SDGs 14b and 2.3. Resolution 70/1 of 25 September 2015, Transforming our world: the 2030 Agenda for Sustainable Development (UN Doc. A/RES/70/1, 21 October 2015).

18 See respectively UNGA, Resolution 60/251 of 3 April 2006 on the Human Rights Council (2006); and Rules of Procedure of the Committee on Fisheries, in: FAO, Basic Texts of the Food and Agriculture Organization of the United Nations, Volumes I and II, 2017, 109-116). 
movements and human rights organizations, which eventually reached a political and intellectual engagement with the Human Rights Council (HRC), a subsidiary body of the UN General Assembly (UNGA). 19 The SSF Guidelines, in turn, were the outcome of a multi-stakeholders process, pledged with the support of small-scale fishers and fishing communities, and ultimately endorsed by the Committee on Fisheries (COFI), ${ }^{20}$ a subsidiary body of FAO Council.

The formal negotiation of the UNDROP commenced in 2012 with the establishment by the HRC of an open-ended intergovernmental working group (HRC Working Group) dedicated to drafting and negotiating the Declaration, which was finalised and adopted by the UNGA in 2018. ${ }^{21}$ The process that led to the negotiation and adoption of the UNDROP started decades earlier, outside of the UN: La Via Campesina took the lead in the organization of a global, bottom-up agrarian movement 'to articulate the vision of a locally controlled food system' that takes stock of 'wide-ranging livelihood strategies' embedded in close relationships with rural areas. ${ }^{22}$ As a result, the Declaration of La Via Campesina on the Rights of Peasants - Women and Men was adopted. The document was used as a starting point of the UNDROP drafting process. La Via Campesina and other international organizations representing rural constituencies from across the world continued to provide 'extensive inputs' to the HRC Working Group. ${ }^{23}$

Stakeholder engagement in the development of the SSF Guidelines was managed by FAO. In 2006, the UNGA mandated FAO to develop an instrument on SSF, ${ }^{24}$ which was supported in 2008 by the Global Conference on SSF.25 The development of the text, however, was only formally initiated by a decision of COFI in $2011,{ }^{26}$ from which a series of global and regional consultative meetings and similar events engaged over 4,000 stakeholders, including small-scale fishers and their communities. ${ }^{27}$ Then the draft text

19 UNHRC, Report of the Human Rights Council on its Thirty-Ninth Session, 23 November 2018, UN Doc. A/HRC/39/2 (2018) 191p. (2018)

20 FAO, Report of the Thirty-first Session of the FAO Committee on Fisheries (9-13 June 2014 FIPI/R1101/2015, 2014).

21 The resolution was adopted by a recorded vote of 23 to 9 , with 15 abstentions. Those countries voting against were Austria, Belgium, Czech Republic, Hungary, Italy, Poland, Romania, Spain and the United States of America. See UNHRC, Resolution 21/19 of 11 October 2012 on the Promotion and Protection of the Human Rights of Peasants and Other People Working in Rural Areas (Adopted at the 21st Session of the Human Rights Council, $\mathrm{A} / \mathrm{HRC} / \mathrm{RES} / 21 / 19,2012)$.

22 L. Cotula, 'Between Hope and Critique: Human Rights, Social Justice and Re-imagining International Law from the Bottom Up' (2020) 48 Georgia Journal of International and Comparative Law 473, 505-508.

23 ibid, 506; E. Riedel, G. Giacca and C. Golay, 'The Development of Economic, Social, and Cultural Rights in International Law' in E. Riedel, G. Giacca and C. Golay (eds), Economic, Social, and Cultural Rights in International Law: Contemporary Issues and Challenges (Oxford University Press 2014), 5-6.

24 See UNGA, Resolution 61/105 Sustainable fisheries, including through the 1995 Agreement for the Implementation of the Provisions of the United Nations Convention on the Law of the Sea of 10 December 1982 relating to the Conservation and Management of Straddling Fish Stocks and Highly Migratory Fish Stocks, and related instruments (UNGA 61st Session, 8 December, 2006), paras 12 and 97.

25 See FAO, Report of the Global Conference on Small-Scale Fisheries Securing Sustainable Small-scale Fisheries: bringing together responsible fisheries and social development (2008).

26 COFI members 'approved the development of a new international instrument on small-scale fisheries that would drawn on relevant existing instruments, complementing the Code [the CCRF]'. See FAO, Report of the Twenty-Ninth Session of the FAO Committee on Fisheries (31 January-4 February 2011 FIPI/R973, 2011), vii-viii, Para 56.

27 Similarly, other FAO international fisheries instruments have been considered by technical consultations first, followed by consensus-based negotiation at COFI and final adoption by FAO Council. See A. Boyle and C. Chinkin, The Making of International Law (Oxford University Press 2007), 126-128. 
was subjected to a two-sessions high-level technical consultation, and eventually FAO Member States and the European Union (EU) negotiated and agreed on the final text, considering the inputs of intergovernmental organizations, non-governmental organizations and civil society organizations that followed the negotiations as observers. $^{28}$ Finally, in 2014, the SSF Guidelines were endorsed by consensus by representatives of 110 FAO Member States, from all regions. ${ }^{29}$

The level of intergovernmental support was therefore initially much broader for the SSF Guidelines than the UNDROP, and, considering the EU support to the SSF Guidelines, broader overall. Following a majority vote at the HRC, ${ }^{30}$ the Declaration gained 121 countries votes in its favour at the UNGA, while Australia, New Zealand, Sweden, the UK and the US voted against the Declaration, and EU Member States, Canada, Japan, Norway, the Republic of Korea, and the Russian Federation abstained. ${ }^{31}$ The lack of support to the UNDROP from high-income countries may be due to the fact that UNDROP's text is articulated in prescriptive terms (consistent use of the verb shall) and explicit references to having the right to, to reflect the explicit intent of clarifying how existing international legally binding instruments on human rights apply in the specific case of peasants. ${ }^{32}$ Those countries characterized by industrialized food production may have thus been reluctant towards the UNDROP's recognition of peasants' 'vision' embedded in traditional local food production. ${ }^{33}$ In contrast, the SSF Guidelines are framed as recommendations (characterized by the predominant use of should and recognise), which may have facilitated adoption by consensus. ${ }^{34}$

Another consequence of the differing levels of intergovernmental support for these instruments is that the UNDROP and the SSF Guidelines are subject to different followup processes, which has relevance to understanding their respective legal strength as soft law. ${ }^{35}$ The COFI has supported the implementation of the SSF Guidelines through planning instruments, including the FAO's Global Assistance Programme in 2014, its Umbrella Programme for the promotion and application of the SSF Guidelines established in 2015, and the development of an SSF Guidelines Global Strategic Framework from 2016 onwards. ${ }^{36}$ The SSF Umbrella Programme, for instance, has four

28 FAO, Securing Sustainable Small-Scale Fisheries: Update on the Development of the Voluntary Guidelines for Securing Sustainable Small-Scale Fisheries in the Context of Food Security and Poverty Eradication (SSF Guidelines) (FAO 2014), 4-5.

29 See footnote supra (n 20).

30 See footnote supra (n 21). Note that the HRC is composed by 47 Member States: UNHRC, 'Current Membership of the Human Rights Council for the 14th cycle, 1 January - 31 December 2020' (2020) $<$ https://www.ohchr.org/en/hrbodies/hrc/pages/currentmembers.aspx > accessed 30 April 2021.

31 UNGA, Report of the Third Committee, 55th Plenary Meeting (17 December 2018 UN Doc A/73/PV55, 2018).

32 UNDROP, preamble.

33 Cotula (n 22), 505.

34 FAO, Chairperson's Report of the Technical Consultation on International Guidelines for Securing Sustainable Small-Scale Fisheries (Thirty-first Session of the FAO Committee on Fisheries, 9-13 June 2014, COFI/2014/Inf10, 2014), Para 32.

35 Such feature has been argued for blurring the boundaries between hard law and soft law, where the latter mimics the former's compliance mechanisms. See C. Redgwell, 'International Soft Law and Globalization' in B. Barton and others (eds), Regulating Energy and Natural Resources (Oxford Scholarship Online 2006).

36 In the subsequent meetings of COFI, both the $32^{\text {nd }}$ and $33^{\text {rd }}$ sessions held respectively in 2016 and 2018, the attending Member States have discussed the implementation of the SSF Guidelines. See FAO, Securing Sustainable Small-Scale 
interrelated components aimed at awareness-raising, strengthening the science-policy interface, empowering stakeholders and supporting implementation. ${ }^{37}$ These activities by FAO, governments and stakeholders have been advancing the implementation of the SSF Guidelines, ${ }^{38}$ including through providing legislative guidance. ${ }^{39}$ With respect to a follow-up mechanism for the UNDROP, scholars have put forward recommendations ranging from establishing a new dedicated UN Special Procedure (e.g. UN Special Rapporteur, Independent Expert or Working Group), engaging and reinforcing existing human rights monitoring mechanisms to assess the UNDROP's implementation, and drafting implementing legislation. ${ }^{40}$

It would be desirable to see mutual supportiveness of these two instruments in such respect as well. FAO's activities on SSF could support the UNDROP's implementation by deepening the understanding of human rights and building capacity to respect and monitor them in the fisheries sector at different scales. Monitoring activities of international human rights bodies could also rely on the SSF Guidelines to better understand how human rights might be supported or hindered in the fisheries sector. To that end, FAO and the diverse UN Human Rights treaty bodies and special procedures should explore forms of collaboration.

\section{The nuances underpinning the concept of 'small-scale fisheries'}

There is no universally agreed definition of 'small-scale fisheries'. This term is multifold as academic scholarship has developed various methodologies to measure 'smallscale' or 'artisanal' fisheries, ${ }^{41}$ which are often associated to numerous other terminologies like coastal, nearshore, customary, traditional fisheries as well. Experts in the field underscore that a single, universal and rigid definition of SSF would be

Fisheries: Towards Implementation of the Voluntary Guidelines for Securing Sustainable Small-Scale Fisheries in the Context of Food Security and Poverty Eradication (SSF Guidelines) (COFI 32nd Session, Doc COFI 2016/7, April, 2016); FAO, Small-Scale and Artisanal Fisheries Governance (COFI 33rd Session, Doc COFI/2018/7, March, 2018). See also FAO, Global Strategic Framework in support of the implementation of the Voluntary Guidelines for Securing Sustainable Small-Scale Fisheries in the context of food security and poverty eradication .

37 FAO, Securing Sustainable Small-Scale Fisheries: Towards Implementation of the Voluntary Guidelines for Securing Sustainable Small-Scale Fisheries in the Context of Food Security and Poverty Eradication (SSF Guidelines), para 18; FAO, Enhancing the contribution of small-scale fisheries to food security and sustainable livelihoods .

38 Notably, some countries (Cambodia, Costa Rica, Ecuador, Guinea, Peru, Sri Lanka and Tanzania) have been identified in taking specific steps to implement the SSF Guidelines at national level, including the review and development of legal frameworks as of the case of Cambodia and Costa Rica. See FAO, Update on Progress to Develop the Global Strategic Framework in Support of the Implementation of the Voluntary Guidelines for Securing Small-Scale Fisheries in the Context of Food Security and Poverty Eradication (SSF-GSF) (COFI 33rd Session, COFI/2018/SBD23, July, 2018), 6. See also J. Nakamura, R. Chuenpagdee and M. El Halimi, 'Unpacking legal and policy frameworks: A step ahead for implementing the Small-Scale Fisheries Guidelines' (2021) 129 Marine Policy 1.

39 See FAO, Legislating for Sustainable Small-Scale Fisheries - A guide and considerations for implementing aspects of the Voluntary Guidelines for Securing Sustainable Small-Scale Fisheries in the Context of Food Security and Poverty Eradication in national legislation (FAO, 2020).

40 P. Claeys and M. Edelman, 'The United Nations Declaration on the rights of peasants and other people working in rural areas' (2020) 47 The Journal of Peasants Studies 1, 10-11 and 43.

41 See D. Gibson and U. R. Sumaila, 'Determining the degree of 'small-scaleness' using fisheries in British Columbia as an example' (2017) 86 Marine Policy 121; Y. Rosseau and others, 'Defining global artisanal fisheries' (2019) 108 Marine Policy 103634; H. Smith and X. Basurto, 'Defining Small-Scale Fisheries and Examining the Role of Science in Shaping Perceptions of Who and What Counts: A Systematic Review’ (2019) 6 Front Mar Sci 1. 
unpractical and ineffective to capture the diverse and dynamic forms of SSF around the world. ${ }^{42}$ The flexibility of the notion, instead, allows for conveying the 'considerable diversity of contexts, from the social differentiation that typically exists in rural areas, of the blurred lines between rural and urban worlds, and from overlapping and often shifting registers of social identity'. ${ }^{43}$

Accordingly, the SSF Guidelines, the UNDROP and other relevant international instruments ${ }^{44}$ do not define SSF, which creates uncertainty as to who is entitled to special protection and preferential rights. Each country and, pursuant to the respective political and legal systems, different levels of government within the same country (e.g. state, province, municipality) can thus develop a definition of SSF that corresponds more closely to the realities of SSF locally. In practice, however, public institutions do not take SSF into account appropriately, ${ }^{45}$ let alone provide clear and consistent statements of what SSF is in their spheres of operation. It follows that policy-, law- and decision-makers, as well as fisheries managers, are likely to refer and treat SSF based on subjective, possibly ideological, and often undesirable interpretations. ${ }^{46}$

The SSF Guidelines provide guidance to governments and other actors by illustrating what small-scale fishing, small-scale fisher, or small-scale fish worker ${ }^{47}$ relate to. The SSF Guidelines rather refer to SSF as a fisheries subsector, ${ }^{48}$ which 'serves as an economic and social engine' (for local economies and communities livelihoods) ${ }^{49}$ 'along the value-chain - pre-harvest, harvest and post-harvest'. ${ }^{50}$ In addition, the SSF

42 They stem from the context-specific feature of SSF, which varies largely by and within communities at any level of governance; the numerous SSF definitions that can be found in scientific literature and legislation, which in turn are based on different criteria and mostly on technological parameters (e.g. boat size, type of fishing gear, motor power, etc); the diversity and dynamism in SSF fishing activities. See Smith and Basurto; R. Chuenpagdee and S. Jentoft, 'Transforming the Governance of Small-Scale Fisheries' (2018) 17 Maritime Studies 101, 105-106; D. J. Mills and others, 'Small-scale Fisheries in the Developing World' in R. Pomeroy and N. L. Andrew (eds), Small-Scale Fisheries Management: Frameworks and Approaches for the Developing World (CAB International 2011), 1; D. S. Johnson, 'The Values of Small-Scale Fisheries' in D. S. Johnson and others (eds), Social Wellbeing and the Values of Smallscale Fisheries, vol 7 (Springer International Publishing AG 2018), 3-7; S. Funge-Smith, Towards Statistical Definition of Small-Scale Fisheries: A matrix scoring approach to characterization of the scale of fishing units (Working paper CWP-IS/2019/11 Twentyseventh Meeting of the Fisheries Subject Group, Coordinating Working Party on Fishery Statistics, Rome, 15-18 May 2019, 2019).

43 Cotula (n 22), 514.

44 For instance, the Agreement on Port State Measures Agreement to Prevent, Deter and Eliminate Illegal, Unreported and Unregulated Fishing (Adopted on 22 November 2009, in Rome, Italy, entered into force on 5 June 2016) exempts 'artisanal subsistence fishing' from the scope of its application without defining it (art. 3(1)(a)(b)). This also points to the need for a definition of 'subsistence': D. Owen pers. comm. on 05 June 2019.

45 S. W. Purcell and R. S. Pomeroy, 'Driving small-scale fisheries in developing countries' (2015) 2 Frontiers in Marine Science 1; D. J. Mills and others, 'Under-reported and Undervalued: Small-scale Fisheries in the Developing World' in R. Pomeroy and N. L. Andrew (eds), Small-scale Fisheries Management: Frameworks and Approaches for the Developing World (CAB International 2011).

46 SSF is commonly perceived under a negative narrative that places them as part of the problem in fisheries sustainability, instead of elevating their contributions to the solution (in social, economic and environmental terms). The importance of changing this narrative to be a more positive and inclusive one was highlighted in a recent symposium held at FAO. See FAO, Proceedings of the International Symposium on Fisheries Sustainability: strengthening the science-policy nexus (FAO Headquarters, 18-21 November 2019 FAO Fisheries and Aquaculture Proceedings No 65 Rome, 2020), 27-28.

47 SSF Guidelines, sec. 2.4.

48 ibid, preface, para 5.

49 ibid, foreword, para 1-2.

50 ibid, preface, para 3. 
Guidelines avoid differentiating ${ }^{51}$ among small-scale commercial artisanal, semiindustrial, subsistence, and arguably recreational, fishing activities. ${ }^{52}$ They also note that small-scale fishers and fish workers often are 'self-employed and engaged in directly providing food for their household and communities as well as working in commercial fishing, processing and marketing'. ${ }^{53}$ Finally, the SSF Guidelines do not limit the understanding of SSF actors to those solely engaged in fishing operations and related activities, but rather include 'fishers, fish workers, their communities, traditional and customary authorities, and related professional organizations and [civil society organizations]. 54

Under UNDROP, in turn, the definition of a 'peasant' includes a person who 'seeks to engage alone, or in association with others or as a community' in artisanal and small-scale fishing and 'related occupation in a rural area' 'for subsistence or for the market'. 55 Similarly to the SSF Guidelines, this definition is broad enough to encompass people involved in multiple activities which SSF is associated, including related preparatory works and cultural practices (e.g. net making and mending, boat maintenance) conducted by fishers and fishing communities on land. ${ }^{56}$ The Declaration also applies to hired workers, which helps broadly encompass professional small-scale fishers along the supply and value-chain, and includes all migrant and seasonal workers on aquaculture farms, ${ }^{57}$ who may have an alternative occupation as small-scale fisher. ${ }^{58}$

In addition, UNDROP sets out two parameters to understand peasants: (i) reliance on family labour or other non-monetized way of organizing labour, and (ii) special dependency on and attachment to the land. 59 So one difficulty arises as to whether references to land could be interpreted, literally, as referring only to inland small-scale fisher peasant - who conducts SSF or small-scale aquaculture in inland waters e.g. rivers, lakes, lagoons, etc. ${ }^{60}$ Other articles of the Declaration, however,

51 Although such distinction remains important for the production of disaggregated fisheries catch data. See D. Pauly and D. Zeller, 'Catch reconstructions reveal that global marine fisheries catches are higher than reported and declining' (2016) Nature Communications 7.

52 While recreational fishing is often seen as a different sector than SSF, recreation may be part of the 'multifunctionality' practices in SSF. See FISHINMED, Small-Scale Fisheries Multifunctionality Best Practices (Report prepared under the ENPI CBC Mediterranean Sea Basin Programme 2007-2013, 2013).

53 SSF Guidelines, preface, para 4.

54 ibid, sec. 2.3.

55 UNDROP, art. 1(1).

56 See S. Jentoft and A. Eide (eds), Poverty Mosaics: Realities and Prospects in Small-Scale Fisheries (Springer 2011 ).

57 UNDROP, art. 1(3).

58 The migratory move of small-scale fishers occurs for different purposes other than fishing, often constituting a way of life. See I. N. Wanyonyi and others, 'Artisanal Fisher Migration Patterns in Coastal East Africa' (2016) 119 Ocean \& Coastal Management 93.

59 Art. 1(1) reads: "For the purposes of the present Declaration, a peasant is any person who engages or who seeks to engage alone, or in association with others or as a community, in small-scale agricultural production for subsistence and/or for the market, and who relies significantly, though not necessarily exclusively, on family or household labour and other non-monetized ways of organizing labour, and who has a special dependency on and attachment to the land".

60 In effect, UNDROP applies to all workers on 'farms in aquaculture', thereby dispelling the misconception that smallscale fisher peasants use their land only for capture fisheries. Aquaculture is often categorised as a fishing-related activity, and it does occur at artisanal and small-scale in certain parts of the world. For example, see A. Suzuki and V. Hoang, 'Better Management Practices and their Outcomes in Shrimp Farming: Evidence from Small-Scale Shrimp Farmers in Southern Vietnam’ (2018) 26 Aquaculture International 469; L. A. Henriquez-Antipa and F. Carcamo, 
support a broader interpretation that encompasses marine SSF as well, ${ }^{61}$ including in marine areas over which coastal States and archipelagic States exercise sovereignty and jurisdiction in similar ways to their land mass, as these actually represents an extension of the land seawards. This argument is supported by key concepts of the UN Convention on the Law of the Sea, which represent customary international law: 62 internal waters, the territorial sea and the archipelagic waters are areas over which coastal States and archipelagic States exercise sovereignty and jurisdiction, ${ }^{63}$ and where the majority of SSF and small-scale aquaculture operate due to their proximity to land and the technical inability of small-scale operations to occur offshore. ${ }^{64}$ These legal concepts should be related to peasants' traditional or customary relationship with land utilized for their SSF activities, including inland and marine waters falling under the sovereignty of coastal States and archipelagic States, all waters of which correspond to their fishing grounds. ${ }^{65}$ This interpretation of the UNDROP as broadly applying to inland and marine SSF resonates with the SSF Guidelines, which, while being focused on marine capture fisheries, ${ }^{66}$ apply to $\mathrm{SSF}$ 'in all contexts', ${ }^{67}$ 'in both marine and inland waters', ${ }^{68}$ as well as to small-scale aquaculture. ${ }^{69}$ Through these two features, the UNDROP emphasizes SSF peasants 'intimate connection' with fishing resources and fishing grounds, either in inland or at sea as 'a source of social identity.'70

The linkages between fisheries and land become clearer in UNDROP provisions on governance of tenure, discussed below. ${ }^{71}$ For present purposes, it is worth noting that the SSF Guidelines recognize the importance of land tenure rights in the coastal/waterfront area 'for ensuring and facilitating access to the fishery, for accessory activities (including processing and marketing), and for housing and other livelihood support'. ${ }^{72}$ It also underscores that '[m] any small-scale fishers, fish workers and their

'Stakeholder's Multidimensional Perceptions on Policy Implementation Gaps regarding the Current Status of Chilean Small-scale Seaweed Aquaculture' (2019) 103 Marine Policy 138.

61 UNDROP, arts. 17(1) and 21(4).

62 R. R. Churchill and V. Lowe, The Law of the Sea (Dominic McGoldrick ed, 3rd edn, Manchester University Press 1999), 60-61, 77-80 and 129-130.

63 United Nations Convention on the Law of the Sea (Adopted 10 December 1982, entered into force 16 November 1994) 1883 UNTS 397 (LOSC), arts. 2, 3, 48 and 49.

64 In this respect, the UN Convention on the Law of the Sea is limited to provisions that aim to protect fisheries in zones under sovereignty from unpermitted foreign fishing vessels or to require regulation on the conservation of living resources. See M. Tsamenyi and Q. Hanich, 'Fisheries Jurisdiction under the Law of the Sea Convention: Rights and Obligations in Maritime Zones under the Sovereignty of Coastal States' (2012) 27 The International Journal of Marine and Coastal Law 783, 785-786.

65 The term 'fishing grounds' is referred to in the FAO's Code of Conduct for Responsible Fisheries, footnote supra (n 9). According to art. 6.18 of the Code, "States should appropriately protect the rights of fishers and fishworkers, particularly those engaged in subsistence, small-scale and artisanal fisheries, to a secure and just livelihood, as well as preferential access, where appropriate, to traditional fishing grounds and resources in the waters under their national jurisdiction".

66 SSF Guidelines, sec. 2.2.

67 ibid, sec. 2.1 .

68 ibid, sec. 2.2 .

69 For more on small-scale aquaculture, see footnote supra (n 61) and B. Belton and D. C. Little, 'Contemporary Visions for Small-Scale Aquaculture' in R. Chuenpagdee (ed), World Small-Scale Fisheries: Contemporary Visions (Eburon Delft 2011).

70 Cotula (n 22), 513.

71 See subsection below on 'land tenure and rights to natural resources'.

72 SSF Guidelines, preface. 
communities - including vulnerable and marginalized groups - are directly dependent on access to fishery resources and land'. ${ }^{73}$ The references, in both UNDROP and the SSF Guidelines, to dependency on land ${ }^{74}$ need to be understood, in as far as certain smallscale fishers also self-identify as indigenous peoples, ${ }^{75}$ in light of the human right of indigenous peoples to "maintain and strengthen their distinctive spiritual relationship with their traditionally occupied and otherwise used lands, territories, waters and coastal seas and other resources', as provided by the UN Declaration on the Rights of Indigenous Peoples. ${ }^{76}$ Similar considerations apply in as far as SSF communities selfidentify as 'traditional communities' under the UN Framework Principles on Human Rights and the Environment77 and/or 'local communities' under the Convention on Biological Diversity (CBD). ${ }^{78}$

On the whole, the UNDROP and the SSF Guidelines are aligned in providing a broad and flexible notion of small-scale fisheries, while calling attention to key features that provide the rationale for international human rights protection. This reflects observations in the literature that, '[w] hat is interesting and important about smallscale fisheries, therefore, is not their scale per se, but all that they are associated with... inherent and related features'. ${ }^{79}$ The choice of the term 'peasant' under the UNDROP serves to capture the multiple grounds of discrimination experienced by individuals and communities in SSF such as expropriation of land, forced evictions and displacement, gender discrimination, the absence of agrarian reform and rural development policies, the lack of minimum wage and social protection, and the repression and criminalization of movements protecting their rights. ${ }^{80}$ These persisting discriminatory treatments have hindered the ability of peasants, including small-scale fishers and fish workers, to have their voice heard, defend their human rights and tenure rights, secure sustainable use of natural resources that they depend on. ${ }^{81}$ They have also precluded the appreciation and recognition of peasants, present and future contributions to development and to conserving and improving biodiversity, which constitute the basis of food production throughout the world.82 The SSF Guidelines also shed light on vulnerable and marginalised groups in SSF, pointing to dependency on access to fishery resources and land, unequal power relations, isolation, limited opportunities, poverty, environmental threats and impacts, as well as the high interdependence and

73 ibid, preface.

74 ibid, preface; UNDROP, art. 1(1).

75 'Self-identification' and the 'special relationship with ancestral lands' are the '[o]nly two of the [six] listed criteria essential to be considered essential for a community to be considered as an indigenous people': ILA, Final Report on the Rights of Indigenous Peoples (International Law Association, SOFIA Conference) (2012), 2-3.

76 UNDRIP, art. 25.

77 UNHRC, Report by Special Rapporteur John H. Knox on the issue of human rights obligations relating to the enjoyment of a safe, clean, healthy and sustainable environment (UN Doc A/HRC/37/59, 2018), Framework Principle 15.

78 Convention on Biological Diversity (5 June 1992, entered into force 29 December 1993) 1760 UNTS 79 (CBD), arts. $8(j)$ and $10(c)$.

79 See S. Jentoft, 'Walking the talk: implementing the international voluntary guidelines for securing sustainable smallsscale fisheries' (2014) 13 Maritime Studies 1, 3.

80 Riedel, Giacca and Golay (n 23), 8.

81 UNDROP, preamble.

82 ibid, preamble. 
competition of SSF with large-scale fisheries, tourism, aquaculture, agriculture, energy, mining, industry and infrastructure development. ${ }^{83}$

\section{Mutual supportiveness between UNDROP and the SSF Guidelines}

Both the UNDROP ${ }^{84}$ and the SSF Guidelines ${ }^{85}$ support the application of international human rights standards to SSF, but they do so from different (albeit, arguably, compatible) perspectives. The Declaration articulates directly specific international human rights standards from the perspectives of peasants as rightsholders, thereby clarifying States' obligations. The SSF Guidelines, in turn, focus on advancing food security and environmental sustainability, taking a "human rights-based approach." 66 On that basis, the SSF Guidelines identify good practices in the use and management of natural resources, emphasizing the role of small-scale fishers as agents in environmental conservation and management, 87 and as benefit-holders of the social development, security and safety that is the responsibility of the State to deliver.

The Declaration makes more explicit the link between SSF communities' right to adequate standard of living and 'concrete, productive dimensions' and 'real-life factors' 88 such as having the right to facilitated access to means of production, production and processing, as well as technical assistance, credit, instance, which are necessary to gain access to local, national and regional markets at prices that guarantee them a decent income and livelihood. ${ }^{89}$ State discretion is clearly limited by human rights standards under UNDROP, clarifying States' specific duties vis-à-vis peasants in SSF and the inter-linkages between concurrent human rights obligations (such as nondiscrimination, access to effective remedies, the protection of human rights defenders). Consequently, the UNDROP points towards the need to address systemic and engrained sources of discrimination, the multiple dimensions of poverty, and the underlying need to support the voice, vision and control over resources of small-scale fishers as part and parcel of the protection, respect and full realization of their human rights. In comparison, the SSF Guidelines arguably support a more accessible translation of international human rights obligations into action-points that specialized managers and decision-makers are expected to implement, focusing on sector-specific means to address the real-life factors upon which the respect and enjoyment of SSF communities' human rights depend.

83 SSF Guidelines, preface.

84 UNDROP, arts. 2(4) and 3(1).

85 SSF Guidelines, sec. 3.1(1).

86 ibid, sec. 1.2.

ibid, secs. 5.5, 5.13, 5.14 and 11.6.

88 Cotula (n 22), 510.

89 UNDROP, art. 16. 
Against this background, the following sub-sections will identify similarities and differences, as well as opportunities for mutually supportive interpretations between the two instruments, in relation, specifically to land tenure and control over natural resources, traditional knowledge, and procedural rights.

\subsection{Land tenure and control over natural resources}

One important feature of both instruments is their recognition and protection of legitimate tenure rights to land (which, as argued above, extends to fishing grounds in both inland and marine waters). Recalling the FAO Voluntary Guidelines on the Responsible Governance of Tenure of land, fisheries, and forests in the context of national food security (Tenure Guidelines), ${ }^{90}$ both the SSF Guidelines and the UNDROP consider legitimate tenure rights as including customary tenure rights as in nonconventional and traditionally regulated tenure systems, of lands ${ }^{91}$ and natural resources, ${ }^{92}$ as well as the restoration of the relevant peoples' access to their land in cases of natural disasters and/or armed conflict. ${ }^{93}$ The two instruments safeguard SSF peasants from arbitrary displacement from their land or from other natural resources. ${ }^{94}$ The instruments, however, diverge in the terms in which they address access to resources and environmental sustainability. They also differ in how they refer to the need of impact assessments, consultation/consent and benefit-sharing to ensure control over the use of resources.

Both the UNDROP and the SSF Guidelines provide for the facilitation of equitable access through redistributive reform. ${ }^{95}$ The Declaration contains an express obligation to give priority to small-scale fishers, together with other peasants, in the allocation of public lands, fisheries and forests, in line with the immediate relationship it establishes between land (including fishing grounds, as discussed above) and the attainment of an adequate standard of living. ${ }^{96}$ In addition, under the UNDROP the 'right to land' establishes a more immediate relationship between the control of fishing grounds and the attainment of an adequate standard of living for small-scale fishers. ${ }^{97}$ This arguably provides 'a more explicit normative foundation for redistributive agrarian reforms'. ${ }^{98}$ In comparison, the SSF Guidelines call for the appropriate granting of preferential access of small-scale fishers to land, fishery resources and to fish in waters

90 FAO, Voluntary Guidelines on the Responsible Governance of Tenure of land, fisheries and forests in the Context of National Food Security (Adopted at the 38th (Special) Session of the Committee on World Food Security, in Rome, on 22 May 2012) (2012).

91 SSF Guidelines, sec. 5.1 and 5.4; UNDROP, art. 17(3).

92 SSF Guidelines, sec. 5.1, 5.3 and 5.4; UNDROP, arts. 5, 12(5) and 17(7).

93 SSF Guidelines, sec. 5.12; UNDROP, art. 17(5).

94 SSF Guidelines, sec. 5.9; UNDROP, art. 17(4).

95 SSF Guidelines, sec. 5.4; UNDROP, art. 17(6).

96 See Cotula (n 22), 508-513.

97 ibid (n 22), 508-513, which refers more generally to the notion of terrestrial land.

98 ibid (n 22), 509. 
under national jurisdiction, as well as 'exclusive zones for small-scale fisheries', 99 'comanagement'. ${ }^{100}$

The Declaration's provision on the right to have access to, sustainably use and manage 'land and the water bodies, fisheries, pastures and forests therein' 101 serve to bring attention to the various habitats in which small-scale fishing communities may conduct activities, not only limited to fishing, but also alternative or complementary livelihoods during closed seasons, closed areas or in the event of disasters and crisis where fishing is not an option. The Declaration also recalls the CBD's duty to conserve and sustainably use biodiversity, connecting it with the need 'to promote and protect the full enjoyment of the rights of peasants and other people working in rural areas'.102 Such environmental standards are reflected in the SSF Guidelines through the ecosystem approach to fisheries. The latter entails both involving small-scale fishers in sustainably managing fishery resources for the benefit of habitats, biodiversity and ecosystems wellbeing, and ensuring that small-scale fishers can benefit from fishery resources maintained by healthy ecosystems. ${ }^{103}$

\subsubsection{Safeguards}

Both instruments refer to three key safeguards for the respect and protection of the rights to land tenure (including fishing grounds) and natural resources: impact assessments, consultation and benefit-sharing. These standards have emerged at the crossroads of international human rights law jurisprudence on indigenous peoples and international biodiversity law,104 and are also recognized in the UN Framework Principles on Human Rights and the Environment. ${ }^{105}$

The first safeguard is the undertaking of prior impact assessments, which cover the analysis of potential environmental impacts, as well as the social and cultural impacts that peasants and people in SSF may suffer. The UNDROP more broadly requires such studies prior to the permission of any exploitation affecting natural

99 For example, Angola's fisheries act restricts the four nautical miles and the inland waters to the use of fisheries that is of subsistence, scientific research, recreational and/or artisanal natures. In Ghana, an Inshore Exclusive Economic Zone limits the six nautical miles to small semi-industrial, canoes and recreational fishing vessels. See respectively Aquatic and Biological Resources Law (New Fishing Act) No. 6-A/2004 (Angola, Promulgated on 3 September 2004, published in the Republic Gazette No. 81, Series I, Supplement on 8 October 2004), arts. 33, 235(2) and 237; Ghana. Fisheries Act No. 625/2002; sec. 81 and sch.

100 SSF Guidelines, secs. 5.1, 5.3-5.5, 5.7 and 5.15.

${ }^{101}$ UNDROP, art. 17(1).

102 ibid, art. 20(1).

${ }^{103}$ See FAO, The ecosystem approach to fisheries (FAO Technical Guidelines for Responsible Fisheries No 4, Suppl 2 Rome, FAO 2003112 p, 2003). See also the definition of "ecosystem" under the Convention on Biological Diversity (Art 2: "a dynamic complex of plant, animal and micro-organism communities and their non-living environment interacting as a functional unit") and of an ecosystem approach as "a strategy for the integrated management of land, water and living resources that promotes conservation and sustainable use in an equitable way" (CBD Decisions V/6 and VII/11). See also E. Morgera, 'The Ecosystem Approach and the Precautionary Principle' in E. Morgera and J. Razzaque (eds), Encyclopedia of Environmental Law: Biodiversity and Nature Protection Law (pp. 70-80, EE 2017).

104 E. Morgera, 'Under the radar: fair and equitable benefit-sharing and the human rights of indigenous peoples and local communities connected to natural resources' (2019) 23 The International Journal of Human Rights 1098.

105 UNHRC (n 78), Framework Principle 15. 
resources that peasants may hold or use, ${ }^{106}$ which is in line with the UN Framework Principle, whereas the SSF Guidelines limits this requirement to the implementation of large-scale projects. ${ }^{107}$ According to the Framework Principles and other international human rights bodies, these assessments should be in accord with the CBD Akwé: Kon Voluntary Guidelines, which provide concrete and systematic step-by-step indications on how impact assessments should include consideration of exercise of customary laws regarding land tenure, traditional systems of natural resource use, maintenance of genetic diversity through customary management, as well as gender, inter-generational considerations, health, safety, food, livelihoods, social cohesion and mobilization. ${ }^{108}$ Significantly, through these considerations, the Akwé: Kon Voluntary Guidelines recommend considering not only negative, but also positive impacts also from the viewpoint of indigenous peoples and local communities. ${ }^{109}$

The second safeguard concerns consultation and participation in decision-making processes. According to both instruments, SSF communities, indigenous peoples, peasants and other people working in rural areas have the right to 'active, free, effective, meaningful and informed participation' prior to the adoption of decisions that may affect them, also taking into account relevant instruments on indigenous peoples. ${ }^{110}$ The UNDROP, however, requires good-faith consultation broadly, before carrying out natural resources exploitation, and participation in the preparation and implementation of food safety, labour and environmental standards. ${ }^{111}$ The SSF Guidelines, in turn, require consultation specifically prior the implementation of largescale projects; the adoption of policies and management measures related to migration of fishers and fish workers, international trade, climate change and disasters, inland and marine spatial planning; and the setting of research priorities. ${ }^{112}$ Neither provide for the standard of free, prior and informed consent (FPIC), which is instead emphasized in UNDRIP and the UN Framework Principles. ${ }^{113}$

In effect, international human rights law instruments on indigenous peoples' rights and international biodiversity law have called more specifically for consulting with indigenous peoples to obtain their FPIC before taking or approving any measures that may affect their lands, territories, or resources, on the basis of access to all relevant information in understandable and accessible forms. ${ }^{114}$ The Inter-American Court of Human Rights underscored the need for 'special and differentiated' consultation processes when the interests of indigenous and tribal peoples may be affected, ${ }^{115}$ with the public interest test set at a higher threshold because their physical and cultural

\footnotetext{
106 UNDROP, art. 5(2).

107 SSF Guidelines, sec. 5.10.

108 CBD CoP7, Decision VII/16 'Article 8(j) and related provisions', UNEP/CBD/COP/DEC/VII/16 (13 April 2014), annex, F, para 19.

109 E. Morgera, 'Justice, Equity and Benefit-Sharing Under the Nagoya Protocol to the Convention on Biological Diversity’ (2015) 24 Italian YB Int'l L 113.

110 SSF Guidelines, sec. 3.1(6); UNDROP, art. 2(3).

111 UNDROP, arts. 5(2)(b) and 10(2).

112 SSF Guidelines, secs. 5.10, 6.10, 7.7, 7.9, 9.2, 9.6 and 11.9.

113 UNHRC (n 78), Framework Principle 15.

114 ibid. (n 78), as summarised in Framework Principle 15.

115 I/ACHR, Case of Kichwa Indigenous Communitiy of Sarayaku v Ecuador (2012), paras 165-166.
} 
survival is at stake. ${ }^{116}$ Accordingly, FPIC should arguably guarantee a "distinguishable voice" for indigenous and tribal peoples within a pluralistic and democratic society in light of their right to decide their own development priorities. ${ }^{117}$ Other international legal materials have recognised FPIC as part of the human rights of non-indigenous communities. ${ }^{118}$ Consensus guidance under the Convention on Biological Diversity, which benefitted from significant inputs from indigenous peoples' representatives, 119 provided further insights on the "prior" and "free" components of FPIC as a continual process building mutually beneficial, ongoing arrangements ${ }^{120}$ that should be free from "expectations or timelines that are externally imposed."121. This formulation fleshes out the characterization of FPIC as a 'constant process of dialogue' advanced in the InterAmerican context ${ }^{122}$ With regard to the "informed" dimension of FPIC, international human rights bodies have also clarified that FPIC should be based on an understanding of the full range of issues and implications entailed by the activity or decision in question. As discussed above, the relationship between FPIC and impact assessment has been explored by human rights bodies with a view to providing indigenous peoples with "full and objective information about all aspects of the project that will affect them, including the impact of the project on their lives and environment". 123 That said, certain States continue to object to the FPIC standard. ${ }^{124}$

The third safeguard is fair and equitable benefit-sharing. The UNDROP calls upon States to 'take measures to ensure that any exploitation affecting the natural resources that peasants traditionally hold or use is permitted based on (...) modalities for the fair and equitable sharing of benefits of such exploitation'. 125 This is in line with international human rights jurisprudence seeking to ensure this safeguard for the

116 ACHPR, Case of Centre for Minority Rights Development (Kenya) and Minority Rights Group International on behalf of Endorois Welfare Council v Kenya (2010), para 212. Compare with K. Gover, 'Settler-State Political Theory, 'CANZUS' and the UN Declaration on the Rights of Indigenous Peoples' (2015) 26 European Journal of International Law 345, 372.

117 In light of ILO Convention 169, Article art 7(1): A. Fuentes, 'Judicial Interpretation and Indigenous Peoples' Rights to Lands, Participation and Consultation. The Inter-American Court of Human Rights' Approach' (2016) 23 International Journal on Minority and Group Rights 39, 74-76 and 79.

118 E.g. UNHRC (n 78), Framework Principle 15; O. De Schutter, Report of the UN Special Rapporteur on the right to food. Promotion and protection of human rights: human rights questions, including alternative approaches for improving the effective enjoyment of human rights and fundamental freedoms (Doc A/67/268 of 8 August 2012, 2012), para 39; ECOWAS, Directive on the Harmonization of Guiding Principles and Policies in the mining Sector (C/DIR3/05/09, 2009); UNDP \& UNEP FAO, Guidelines on Free, Prior and Informed Consent (UN-REDD Programme, 2013), 11-12. See discussion in Morgera (n 111), 1111-1113; and L. Cotula and K. Tienhaara, 'Reconfiguring Investment Contracts to Promote Sustainable Development' in K. P. Sauvant (ed), Reconfiguring Investment Contracts to Promote Sustainable Development (Oxford University Press 2013), 301 and 303.

119 See generally Morgera (n 111).

${ }^{120}$ CBD CoP13, Decision XIII/18 'Article 8(j) and related provisions', CBD/COP/DEC/XIII/18 (17 December 2016), Mo'otz Kuxtal Voluntary Guidelines, para. 6.

${ }^{121}$ ibid, para 14.

${ }^{122}$ I/ACHR, Case of Kaliña and Lokono Peoples v Suriname (2015), Joint Concurring Opinion of Judges Sierra Porto and Ferrer Mac-Gregor Poisot.

${ }^{123}$ See I/ACHR, Saramaka People v. Suriname (2007), para 134; and A. Fodella, 'Indigenous Peoples, the Environment, and International Jurisprudence: Essays in Honour of Tullio Treves' in N. Boschiero and others (eds), International Courts and the Development of International Law (Asser Press 2013), 356 and 360.

${ }^{124}$ See the convoluted title of the CBD, Mo'otz Kuxtal Guidelines (n 122).

${ }^{125}$ UNDROP, art. 5.2.c. 
maintenance of the cultural and physical survival of indigenous peoples. ${ }^{126}$ The SSF Guidelines, in turn, support the 'equitable distribution of the benefits yielded from responsible management of fisheries and ecosystems, rewarding small-scale fishers and fish workers, both men and women'. ${ }^{127}$ In doing so, it emphasizes the role of benefitsharing towards ecosystem stewards as part of an ecosystem approach. ${ }^{128}$ It also conceptualizes benefit-sharing as an incentive for ecosystem stewards' positive contribution to humanity's well-being deriving from the ecosystem services they provide, maintain or restore. ${ }^{129}$ Benefit-sharing can also be understood as recognition for past and present contributions of SSF communities to global environmental objectives and food security, with a view to ensuring that their traditional practices continue in the future. ${ }^{130}$ The SSF Guidelines explicitly link benefit-sharing with nondiscrimination (based on gender, discussed below, and against indigenous peoples), ${ }^{131}$ which is also a dimension recognized under the UN Framework Principles on Human Rights and the Environment. ${ }^{132}$ Furthermore, the SSF Guidelines note the cross-scale dimensions of benefit-sharing, by reference to the need to ensure that small-scale fishing communities benefit from wider economic developments at the local level (such as tourism) ${ }^{133}$ and international trade. ${ }^{134}$ According to CBD Guidelines, benefit-sharing should be explored as early as during environmental impact assessments and be considered intertwined with the partnership-building process of FPIC. 135

These three safeguards (impact assessments, consultation and benefit-sharing) are also relevant to prevent and address gender discrimination ${ }^{136}$ in the context of reforms and resettlement schemes', according to UNDROP,137 and in the designing, planning, and implementation of management measures, according to the SSF Guidelines, ${ }^{138}$ which specifically note the role of benefit-sharing from the management of fisheries and ecosystems for SSF women. ${ }^{139}$ These safeguards can also address other

${ }^{126}$ Eg, I/ACHR, Saramaka People v. Suriname (n 124), para 91; I/ACHR, Case of the Mayagna (Sumo) Awas Tingni Community v. Nicaragua (2001), para 149.

${ }^{127}$ SSF Guidelines, sec. 5.1.

${ }^{128}$ E. Morgera, 'The Need for an International Legal Concept of Fair and Equitable Benefit Sharing' (2016) 27 The European Journal of International Law 353; CBD.

129 CBD CoP5, Decision V/6 'Ecosystem Approach', UNEP/CBD/COP/5/23 (22 June 2000), para 9.

130 Morgera (n 110).

${ }^{131}$ SSF Guidelines, sec. 6.2 .

${ }^{132}$ UNHRC (n 78), UN Framework Principles, para 9; E. Morgera, 'A reflection on benefit-sharing as a Framework Principle on Human Rights and the Environment proposed by UN Special Rapporteur John Knox (Part I)' (BeneLex Blog, 8 April 2018) <https://benelexblog.wordpress.com/2018/04/08/a-reflection-on-benefit-sharing-as-aframework-principle-on-human-rights-and-the-environment-proposed-by-un-special-rapporteur-john-knox-part-i/> accessed 06 October 2020 .

133 SSF Guidelines, sec. 6.8.

134 ibid, secs. 7.8 and 7.10 .

${ }^{135}$ Morgera (n 110) based on combined reading of the CBD Akwé: Kon Voluntary Guidelines and Mo’otz Kuxtal Guidelines.

${ }^{136}$ CEDAW, General recommendation No. 34 on the rights of rural women (Committee on the Elimination of Discrimination against Women, CEDAW/C/GC/34, 4 March, 2016).

${ }^{137}$ UNDROP, art. 4(2)(h).

138 SSF Guidelines, sec. 5.15.

139 ibid, sec. 5.1, emphasis added. 
grounds for non-discrimination, and ensure consideration of the human rights of children. ${ }^{140}$

All these three key safeguards (impact assessments, consultation and benefitsharing), however, have been criticized because they may arguably be 'consistent with the penetration of commercial forms of production' and 'operate in ways that are coextensive with extractivist models'. ${ }^{141}$ In particular, benefit-sharing is often associated with an offer of money or other economic advantage (for instance, employment) in exchange for obtaining consent, ${ }^{142}$ which 'encourages a climate of disrespect towards indigenous peoples'. ${ }^{143}$ Benefit-sharing has resulted in 'attempts to undermine social cohesion of affected communities' through bribes to community leaders or selective negotiations tactics. ${ }^{144}$ In addition, monetary benefit-sharing is known to 'destruct the social network' of indigenous groups, ${ }^{145}$ putting in place self-defeating or paternalistic mechanisms that are not responsive to communities' specific needs. ${ }^{146}$ Regional human rights bodies have thus had occasion to point out to situations in which promised benefit-sharing were not delivered, ${ }^{147}$ or benefit-sharing arrangements were originally in place but broke down, and/or were weakened by ineffective State monitoring of outsiders' activities. ${ }^{148}$

An application of these guarantees, however, that genuinely builds upon international human rights and biodiversity law ${ }^{149}$ can arguably make space for different worldviews of nature and development ${ }^{150}$ embodied in small-scale fishing communities' distinctive ways of life. ${ }^{151}$ In that way, the safeguards can serve to challenge mainstream conceptions of economic development and tackle attempts to bottle SSF

${ }^{140}$ UNHRC, Report of the Special Rapporteur on the issue of human rights obligations relating to the enjoyment of a safe, clean, healthy and sustainable environment (UN Doc A/HRC/37/58, 2018).

${ }^{141}$ Cotula (n 22), 514 and 520.

${ }^{142}$ I/ACHR, Case of Kichwa Indigenous Communitiy of Sarayaku v Ecuador, para 194.

143 ibid, paras 193-194.

144 ibid, para 186; J. Gilbert and C. Doyle, 'A New Dawn over the Land: Shedding Light on Collective Ownership and Consent' in S. Allen and A. Xanthaki (eds), Reflections on the UN Declaration on the Rights of Indigenous Peoples (1st edn, Hart 2011), 289.

145 N. Gomez, 'Indigenous Peoples and Psychosocial Reparations: The Experience with Latin American Indigenous Communities' in F. Lenzerini (ed), Reparations for Indigenous Peoples: International and Comparative Perspectives (Oxford University Press 2008), 143, 158.

146 G. Citrioni and K.Q. Osuna, 'Reparations for Indigenous Peoples in the Case of the Inter-American Court of Human Rights' in F. Lenzerini (ed), Reparations for Indigenous Peoples: International and Comparative Perspectives (Oxford University Press 2008), 317, 340 and 324.

147 ACHPR, para 274.

${ }^{148}$ I/ACHR (n 23), paras 77-84 and 183.

149 As suggested in Morgera (n 111).

150 A. Barros, 'The Fetish Mechanism: A Post-Dogmatic Case Study of the Atacama Desert Peoples and the Extractive Industries' in C. Lennox and D. Short (eds), Handbook of Indigenous Peoples' Rights (Routledge 2016), 223, 231232.

151 G. Pentassuglia, 'Towards a Jurisprudential Articulation of Indigenous Land Rights' (2011) 22 European Journal of International Law 165, 176; D. McGregor, 'Living Well with the Earth: Indigenous Rights and the Environment' in C. Lennox and D. Short (eds), Handbook of Indigenous Peoples' Rights (Routledge 2016), 167, 175; E. Desmet, Indigenous rights entwined with nature conservation, vol 8 (Intersentia 2011), 58 and 175; and F. Francioni, Reparation for Indigenous Peoples: Is International Law Ready to Ensure Redress for Historical Injustices? (Oxford University Press 2008). 
communities' worldviews into neo-liberal or neo-colonial agendas. ${ }^{152}$ To that end, impact assessments, consultation and benefit-sharing need to support communities' agency as tools for a concerned and iterative dialogue aimed at understanding and accommodating different worldviews with a view to enhancing communities' choice and capabilities. ${ }^{153}$ That transformative potential can be supported by better understanding of small-scale fishing communities' needs, values, and priorities as reflected under the UNDROP, so as to inform case-by-case assessments to ensure a culturally appropriate implementation of international human rights law.

In turn, the SSF Guidelines provide a finer-grained understanding of the barriers and opportunities within fisheries governance. They do not indicate how to avoid imposing certain views of development upon SSF communities that could endanger their cultural or physical survival. The SSF Guidelines nevertheless can contribute to the transformative application of the three safeguards by emphasizing the need for providing support for the exercise of SSF communities' rights, in addition to protecting or enhancing communities' control over natural resources (as emphasized by the UNDROP). Together, the two instruments can shift the practice of impact assessments, consultation and benefit-sharing away from a technocratic, damage-control approach towards collaboratively identifying opportunities for creating positive impacts in addition to avoiding potential negative impacts, taking into account SSF communities' views. ${ }^{154}$

\subsection{Traditional knowledge}

The importance of traditional knowledge is recognized by both instruments. ${ }^{155}$ These considerations about knowledge are essential to understand the tensions around environmental sustainability in SSF: whose knowledge (scientific, modern or traditional) determines environmental sustainability approaches in the fisheries sector more broadly? How are the knowledge contributions of small-scale fishers to sustainable fisheries assessed and taken into account in decision-making processes? And whose knowledge determines the limitations imposed upon SSF to ensure sustainable practices?

The UNDROP, which recalls the rights to culture, practices and knowledge, including ways of life, methods of production or technology, ${ }^{156}$ specifically emphasizes traditional ways of fishing and community-based commercialization systems; 157 and the rights to use and protect peasants' traditional medicines, and to maintain their health

\footnotetext{
152 E. Reimerson, 'Between Nature and Culture: Exploring Space for Indigenous Agency in the Convention on Biological Diversity' (2013) 22 Environmental Policy; Y. Uggla, 'What is This Thing Called 'Natural'? The Nature-culture Divide in Climate Change and Biodiversity Policy’ (2009) 17 J Pol Ecology 79.

153 Morgera (n 111). See also a discussion on consultation and free prior informed content at ibid, 14-16.

154 As suggested in Morgera (n 111).

155 SSF Guidelines, sec. 3.1(2), 5.18, 11.4 and 11.7; UNDROP, arts. 18(3), 19(1)(2), 20(2) and 26.

${ }^{156}$ UNDROP, art. 26.

${ }^{157}$ Ibid, art. 16(1).
} 
practices using plants, animals and minerals for medicinal use. ${ }^{158}$ Complementing the UNDROP with a focus on means of implementation, the SSF Guidelines include as one of their objectives 'to enhance public awareness and promote the advancement of knowledge on the culture, role, contribution and potential of small-scale fisheries, considering ancestral and traditional knowledge, and their related constraints and opportunities'. 159 The SSF Guidelines then point to the need for technical and financial assistance to maintain, organize, exchange and improve traditional knowledge of aquatic living resources and fishing techniques. ${ }^{160}$

The UNDROP provides a clear emphasis on the use of traditional knowledge of peasants, including small-scale fishers, in the design and implementation of climate change adaptation and mitigation policies, 161 which is less explicit in the SSF Guidelines. The Declaration affirms their rights in contributing through the 'use of practices and traditional knowledge' in such endeavours whilst the SSF Guidelines do not mention 'traditional knowledge' in its section devoted to disaster risks and climate change. The UNDROP rather calls for full effective consultation with fishing communities, including indigenous peoples, men and women in the development of policies and plans to address climate change in fisheries. ${ }^{162}$ The SSF Guidelines underline the need for support to address climate change, through measures that secure disaster preparedness, emergency response, relief and rehabilitation, and the role of small-scale fishers in supporting energy efficiency in the subsector. ${ }^{163}$ They further call for transparent access to adaptation funds, facilities and culturally appropriate technologies for climate change adaptation. ${ }^{164}$

All these provisions on traditional knowledge are essential to effectively contribute to the recognition of small-scale fishers and their communities' contribution to sustainable development and environmental protection, and equally to give them voice in decision-making processes that may affect their ways of life and livelihoods. ${ }^{165}$ International guidance underscores that respecting traditional knowledge requires valuing equally with, and complementary to, scientific knowledge, in order to promote the full respect for the cultural and intellectual heritage of indigenous and local communities relevant to the conservation and sustainable use of biodiversity. ${ }^{166}$ Actual impact on decision-making, however, depends on whether traditional knowledge holders have sufficient procedural access to the relevant decision-making processes, ${ }^{167}$ as

\footnotetext{
158 ibid, art. 23(2).

159 SSF Guidelines, sec. 1.1.f.

160 ibid, secs. 11.4 and 11.7 .

${ }^{161}$ UNDROP, art 18.3.

162 SSF Guidelines, sec. 9.2.

163 ibid, secs. 9.2-9.8

164 ibid, secs. 9.7 and 9.9 .

165 E. Morgera, 'Fair and Equitable Benefit-sharing at the Crossroads of the Human Right to Science and International Biodiversity Law' (2015) 4 Laws 803.

166 Tkarihwaié:ri Code of Ethical Conduct on Respect for the Cultural and Intellectual Heritage of Indigenous and Local Communities, CBD Decision X/42, annex, preamble.

167 S. Seth, 'Putting Knowledge in its Place: Science, Colonialism and the Postcolonial' (2009) 12 Postcolonial Studies 373,4 .
} 
discussed below. ${ }^{168}$ In addition, even if traditional knowledge is recognized as a form of science, its integration in various decision-making processes may impose unfair burdens on traditional knowledge holders, constraining the further development of knowledge systems in light of changed circumstances, including changes to traditional life styles within which traditional knowledge is rooted. ${ }^{169}$ These considerations point to the need for caution in engaging with traditional knowledge holders and the underlying requirements for impact assessment, consultation and benefit-sharing with traditional knowledge holders, which is clearly recognized in both international human rights jurisprudence on indigenous peoples and international biodiversity law, ${ }^{170}$ but is not explicitly recalled in the UNDROP or the SSF Guidelines. ${ }^{171}$ Nevertheless, the relevance of these safeguards can be read into the UNDROP based on the combined effect of its provisions on traditional knowledge and that on the right of access to natural resources, ${ }^{172}$ as the development and transmission of traditional knowledge are intrinsic to the land tenure (including fishing grounds) and customary governance of natural resources. ${ }^{173}$

Arguably in line with the requirements of consultation and benefit-sharing, ${ }^{174}$ the UNDROP points to the role of the State in encouraging 'equitable and participatory partnerships' with scientists. ${ }^{175}$ This is an important point with regard to the interface between SSF communities' traditional knowledge and technology transfer in the fisheries sector. ${ }^{176}$ While there may be growing political awareness of the benefits that could arise from marine technology transfer to SSF communities, unequal attention has been paid to actual and potential risks, particularly with regard to technologies that seek to enhance the effectiveness of fishing activities. SSF communities' own local technologies are more likely to meet local needs for food, ${ }^{177}$ and be sensitive to the location in which they are applied, the relative abundance of fishing resources, and the complex, traditional resource use rights. ${ }^{178} \mathrm{SSF}$ community-scientists partnerships could thus focus on examining and evaluating 'local-specific, small-scale technologies, coupled with community-oriented, participatory measures to protect the ecological

168 See subsection below on right to water for SSF use.

169 S. Vermeylen, G. Martin and R. Clift, 'Intellectual Property, Rights Systems and the Assemblage of Local Knowledge Systems' (2008) 15 International Journal of Cultural Property 201, 207.

170 UNHRC (n 78), Framework Principle 15. See also Morgera (n 129).

171 Though it has been subject to FAO's technical scrutiny in later studies. See J. Fischer and others (eds), Fishers' knowledge and the ecosystem approach to fisheries: applications, experiences and lessons in Latin America (FAO Fisheries and Aquaculture Technical Paper No. 591. Rome, FAO. 278 pp. 2015).

172 UNDROP, art 5. See section above on social rights and related provisions.

173 This has been recognised internationally, for instance, in the Preamble of the Nagoya Protocol on Access to Genetic Resources and the Fair and Equitable Sharing of Benefits arising from their Utilization to the Convention on Biological Diversity (adopted 29 October 2010, entered into force 12 October 2014): "the interrelationship between genetic resources and traditional knowledge, their inseparable nature for indigenous and local communities,..."

174 Morgera (n 166).

175 UNDROP, art. 25.3.

176 E. Morgera and M. Ntona, 'Linking small-scale fisheries to international obligations on marine technology transfer' (2018) 93 Marine Policy 295.

177 D.S. Johnson, 'Category, narrative, and value in the governance of small-scale fisheries' (2006) 30 Marine Policy 747, 27

178 C. Bailey, D. Cycon and M. Morris, 'Fisheries development in the Third World: The role of international agencies' (1986) 14 World Development 1269, 1271. 
integrity of the living coastal resources', with a view to facilitating 'technology blending' to take advantage, where appropriate, of the positive aspects of other technologies. ${ }^{179}$

Returning to the question of whether the protection of traditional knowledge helps address tensions around the environmental sustainability of SSF, the UNDROP frames these questions in terms of the environmental rights of peasants, ${ }^{180}$ their entitlements to the conservation and sustainable use of rural areas and biodiversity as part of the efforts to protect their traditional knowledge and their right to livelihoods. ${ }^{181}$ The SSF Guidelines, in turn, spell out the environmental duties of people in SSF (e.g. utilize nondestructive fishing practices and energy-efficiency operations), ${ }^{182}$ once again taking the viewpoint of States as implementers of international fisheries law and applying the human rights-based approach to sector-specific contexts. What the Declaration adds, in that connection, is underscoring the need to "challenge ingrained prejudices about the "backwardness", or "modernity," of different systems of livelihoods and beliefs, and of different forms of natural resource use'. ${ }^{183}$ These prejudices indeed 'underpin the structural discrimination that peasants and indigenous peoples experience in many legal systems', 184 and that may be reflected in the mainstream approaches to environmental sustainability in the fisheries sector.

\subsection{Procedural rights}

Access to information, justice and effective remedies are essential procedural rights that bolster the guarantees on tenure and control over natural resources, as well as the protection of traditional knowledge just discussed. ${ }^{185}$ The SSF Guidelines and the UNDROP are both attentive to the need of small-scale fishing communities and peasants to have access to timely and adequate information, especially concerning production, processing, marketing and distribution of their products. ${ }^{186}$ And that information should be provided in a language, form and through means adequate to their culture, so that all the interested people can be offered the opportunity to and decide to appropriately participate in decision-making processes. ${ }^{187}$ Once again focusing on sector-specific means of implementation, the SSF Guidelines emphasize the need for information to ensure the sustainability of SSF, including data on IUU fishing, disaster risks, climate change, livelihoods and food security, ${ }^{188}$ as well as the need to develop

\footnotetext{
179 J. Kurien, Small-scale Fisheries in the Context of Globalisation (1998), 29.

180 That is, the 'right to conservation and protection of the environment and the productive capacity of their lands, and of the resources that they use'. UNDROP, art. 18(1). The UNDROP is limited in providing environmental duties, with the exception of the duty not to store and dispose of hazardous material, substance or waste on peasants' land. See ibid, art. 18(4).

181 ibid, art. 20.

182 SSF Guidelines, secs. 5.14 and 9.8.

183 Cotula (n 22), 520.

184 ibid., 520.

185 UNHRC (n 78), Framework Principles 7 and 10.

186 SSF Guidelines, sec. 7.10; and UNDROP, arts. 11(2) and 25(3).

187 SSF Guidelines, secs. 3.1(7)(8) and 11.8; and UNDROP, art. 11(2).

188 SSF Guidelines, sec. 11.5.
} 
information systems for data-poor conditions. ${ }^{189}$ This is in line with the broader recognition, under the SSF Guidelines, of the importance of access to information for helping SSF communities to 'cope with existing problems and empower them to improve their livelihoods'. ${ }^{190}$

Provisions on access to justice are, in turn, more elaborated in the UNDROP than in the SSF Guidelines. Both require access to impartial and competent judicial and administrative bodies to timely, affordable and effective means of resolving disputes, and provision for prompt remedies such as right of appeal, restitution, indemnity, compensation and reparation. ${ }^{191}$ The UNDROP, however, also highlights the right to legal assistance, providing for legal aid as an additional measure for peasants who would otherwise not have access to administrative and judicial services. ${ }^{192}$ Whereas the SSF Guidelines are limited in only providing for the protection of small-scale fishing communities from arbitrary eviction and protection of their legitimate tenure rights from extinction or infringement, the UNDROP is broader in requiring effective mechanisms for the prevention of and redress for any action aimed at or resulting in the violation of peasants' human rights. ${ }^{193}$

All these procedural dimensions serve to support the voice of small-scale fishers and their communities in the making of decisions that could affect them, and to recognize their contributions to sustainable fisheries and sustainable development more broadly. ${ }^{194}$ They are all essential underpinnings of the human right to natural resources, including its inter-face with gender discrimination and the protection of traditional knowledge discussed above. In other words, while the UNDROP does not recognize the right to food sovereignty as such, ${ }^{195}$ it provides substantive and procedural dimensions underpinning small-scale fishing communities' right to determine their own fisheries systems, ${ }^{196}$ and with that underscores the opportunity to also address poverty as a 'multi-dimensional phenomenon that can be underpinned by marginalization and lack of voice as well as low incomes'. ${ }^{197}$ Attention to practical means of implementation as provided under the SSF Guidelines, however, remains essential, particularly as SSF communities, many of which are located in remote areas, may not be able to take advantage of their procedural rights for logistical reasons. ${ }^{198}$

\footnotetext{
189 ibid, sec. 11.6.

190 ibid, sec. 11.4.

191 ibid, sec. 5.11; UNDROP, art. 12(2).

192 UNDROP, art. 12(3).

193 ibid, art. 12(5).

194 Cotula (n 22), 490-497.

195 UNDROP, art 15.4 reads "Peasants and other people working in rural areas have the right to determine their own food and agriculture systems, recognized by many States and regions as the right to food sovereignty."

196 Cotula (n 22), 505.

197 As Cotula puts it: 'multi-dimensional phenomenon that can be underpinned by marginalization and lack of voice, as well as low incomes'. Ibid, 55.

198 Justice may be brought to SSF communities in remote areas, for instance, as opposed to expecting remote communities to seek justice in central locations. For instance, in Brazil, the so-called itinerant justice enabled communities in remote areas to have access to legal advice and proceedings initiated by civil servants. See J. Nakamura and F. Hazin, 'Assessing the Brazilian Federal Fisheries Law and Policy in light of the Voluntary Guidelines for Securing Sustainable Small-scale Fisheries' (2020) 113 Marine Policy 1, 8.
} 


\section{Linking the UNDROP and the SSF Guidelines to the Sustainable Development Goals}

Both the UNDROP and the SSF Guidelines seek to support the application of international human rights instruments and standards to SSF, and in doing so they are each remarkable in their own field. The UNDROP expands, to SSF, the understanding of the relevance of international human rights law and natural resources, which has mainly been concerned with land-based activities. The SSF Guidelines, in turn, stand out as an innovative international fisheries law instrument, as in that area of international law there is still insufficient integration with human rights. ${ }^{199}$

The UNDROP and the SSF Guidelines engage with similar issues, although from different perspectives. The Declaration articulates directly specific international human rights standards from the perspectives of the rightsholders, including the need to address systemic sources of discrimination, the multiple dimensions of poverty, and the underlying need to support the voice, vision and control of resources of small-scale fisherfolk as part and parcel of the protection, respect and full realization of their human rights. The SSF Guidelines, in turn, mainly take the perspective of duty-bearers. ${ }^{200}$ Applying the human rights-based approach for identifying good practices and sectorspecific means of implementation. This instrument thereby seeks to balance the progressive realization of small-scale fishers' rights with the need to ensure the sustainable management of resources. While the SSF Guidelines may be seen as glossing over the need for more structural approaches, they nevertheless offer a useful complement to the UNDROP, by providing a fine-grained picture of the technicalities that need to be tackled in the fisheries sector, and a more accessible translation of human rights for the specialized managers and decision-makers that are in practice implementing the human rights obligations of States. ${ }^{201}$

Their combined interpretation and application are therefore called for, even when governments may not have supported UNDROP, given the universal, interconnected and indivisible nature of the underlying international commitments to ensure inclusive and fair sustainable development. ${ }^{202}$ To some extent, the SDGs provide the ground for

199 ibid at 2-3.

200 The elaboration on the human rights-based approach and the roles played by duty-bearers and right-holders was further supported by FAO in subsequent activities related to the SSF Guidelines implementation. See S. Yeshanew, N. Franz and L. Westlund, FAO Fisheries and Aquaculture Proceedings. No. 53. Exploring the human rights-based approach in the context of the implementation and monitoring of the SSF Guidelines. (2016).

201 The need to introduce human rights concepts and standards to fisheries professionals is highlighted by Song and Soliman, who also note the hurdle of overcoming mainstream understanding of "fishing rights" as individual tradable commodity, which are geared towards wealth accumulation as opposed to protecting access to fisheries as an "indivisible part of their culture, survival and wellbeing" (p 20). On the other hand, the authors seem to ignore the international human rights approach to balancing of rights and the implications in that context of the international recognition of the inter-dependence of human rights and a healthy environment (p 22-23). A. M. Song and A. Soliman, 'Situating human rights in the context of fishing rights - Contributions and contradictions' (2019) 103 Marine Policy 19.

${ }^{202}$ For a dedicated analysis of these elements of the SDG, their meaning in terms of normativity and in inter alia elevating human rights, justice, political and moral considerations, see G. Long, 'Underpinning commitments of the Sustainable Development Goals: indivisibility, universality, leaving no one behind' in D. French and L. J. Kotzé (eds), Sustainable Development Goals: Law, Theory and Implementation (Edward Elgar Publishing 2018). 
doing so, by including specific targets on access of small-scale fishers to land, marine resources, productive resources and inputs, knowledge, financial services, markets and opportunities for value addition. ${ }^{203}$ But the SDGs address these issues from a technical perspective and the lack of explicit reference to relevant human rights calls into question the suitability of these targets to focus attention on the systemic causes of discrimination that prevent SSF communities from gaining access to these resources and the underlying need to control resources and production as part and parcel of the protection and realization of SSF communities' human rights.

The complexities underlying these targets, however, can be brought to light by reflecting on the widely acknowledged need to pursue the SDGs in a coherent manner and exploring the nexus between SSF-related targets and other SDGs. The respective contributions of UNDROP and the SSF Guidelines can thus guide governments, development operators, and businesses in respecting human rights, as recommended by the HRC, ${ }^{204}$ supporting efforts to realize the SDGs through policy coherence, for instance with reference to SDGs 1 (poverty), 2 (food security), 5 (gender equality), 13 (combating climate change) and 16 (access to justice). Both the UNDROP and the SSF Guidelines offer specific guidance on how to address all these issues, thereby supporting the understanding of the inter-dependencies across SDGs in SSF.

In conclusion, the UNDROP supports an understanding of the daily realities of marginalization of small-scale fishers that connects the good practices identified in the SSF Guidelines to the need to pursue the SDGs in a coherent manner. We thus argue that this understanding should help overcome the challenge of the limited support for the UNDROP by developed states, due to their resistance to embrace the rightsholders' demands to recognize the 'relation between social justice claims and human rights norms' as well as on 'collective rights, on control over the means of production and agricultural value chains'. ${ }^{205}$ Could the opportunities of a mutually supportive interpretation of international fisheries law, international human rights law and international environmental law to the benefit of realizing multiple SDGs rather be the basis for a more constructive engagement of duty-bearers with the rightsholders involved in SSF? This Chapter has partially explored this question by analysing two key instruments for SSF, with a focus on tenure and control of natural resources, as well as the protection of traditional knowledge. Concrete implementation in coherent and complementary ways can be further supported by FAO and international human rights bodies, in their advisory and monitoring activities respectively.

\section{Selected Bibliography}

\footnotetext{
203 See footnote supra (n 17).

204 UNHRC (n 78), Framework Principles 2, 8, 12 and 14.

205 Cotula (n 22), 513.
} 
Cotula L, 'Between hope and critique: Human rights, social justice and re-imagining international law from the bottom up' (2020) 48 Georgia Journal of International and Comparative Law 49

Morgera E, 'Under the radar: fair and equitable benefit-sharing and the human rights of indigenous peoples and local communities connected to natural resources' (2019) 23 International Journal of Human Rights

Nakamura J and Hazin F, 'Assessing the Brazilian Federal Fisheries Law and Policy in light of the Voluntary Guidelines for Securing Sustainable Small-scale Fisheries' (2020) 113 Marine Policy 1

\section{International Instruments}

Convention on Biological Diversity (5 June 1992, entered into force 29 December 1993) 1760 UNTS 79 (CBD)

CBD CoP7, Decision VII/16 'Article 8(j) and related provisions', UNEP/CBD/COP/DEC/VII/16 (13 April 2014)

CBD CoP5, Decision V/6 'Ecosystem Approach', UNEP/CBD/COP/5/23 (22 June 2000)

Tkarihwaié:ri Code of Ethical Conduct on Respect for the Cultural and Intellectual Heritage of Indigenous and Local Communities, CBD Decision X/42

Nagoya Protocol on Access to Genetic Resources and the Fair and Equitable Sharing of Benefits arising from their Utilization to the Convention on Biological Diversity (adopted 29 October 2010, entered into force 12 October 2014)

CBD CoP13, Decision XIII/18 'Article 8(j) and related provisions', CBD/COP/DEC/XIII/18 (17 December 2016), Mo'otz Kuxtal Voluntary Guidelines Code of Conduct for Responsible Fisheries (adopted 31 October 1995, Resolution 4/95 FAO Conference)

Agreement on Port State Measures Agreement to Prevent, Deter and Eliminate Illegal, Unreported and Unregulated Fishing (Adopted on 22 November 2009, in Rome, Italy, entered into force on 5 June 2016)

Voluntary Guidelines for Securing Sustainable Small-scale fisheries in the context of food security and poverty eradication (adopted at the 31st Session of the Committee on Fisheries, 9-13 June 2014) 18p.

Rules of Procedure of the Committee on Fisheries, in: FAO, Basic Texts of the Food and Agriculture Organization of the United Nations, Volumes I and II, 2017, 109-116) 
Migration for Employment Convention (Revised) (Adopted 01 July 1949, entered into force 22 January 1952) (C097)

Work in Fishing Convention (Adopted 14 June 2007, entered into force 16 November 2017) (C188)

Convention on the Elimination of All Forms of Discrimination against Women (Adopted 18 December 1979, entered into force 3 September 1981) 1249 UNTS 13 (CEDAW)

United Nations Convention on the Law of the Sea (Adopted 10 December 1982, entered into force 16 November 1994) 1883 UNTS 397 (LOSC)

Convention on the Rights of the Child (Adopted 20 November 1989, entered into force 2 September 1990) 1577 UNTS 3 (CRC)

UNGA, Resolution 60/251 of 3 April 2006 on the Human Rights Council (2006)

United Nations Declaration on the Rights of Indigenous Peoples, UNGA Res 61/295

(13 September 2007) (adopted by 144 votes to 4; 11 abstentions)

Resolution 70/1 of 25 September 2015, Transforming our world: the 2030 Agenda for Sustainable Development (UN Doc. A/RES/70/1, 21 October 2015)

United Nations Declaration on the Rights of Peasants and Other People Working in Rural Areas, UNGA Resolution A/C.3/73/L.30 (28 September 2018) (adopted by 33 votes to $3 ; 11$ abstentions) (UNDROP)

\section{International Cases}

ACHPR, Case of Centre for Minority Rights Development (Kenya) and Minority Rights Group International on behalf of Endorois Welfare Council v Kenya (2010)

I/ACHR, Case of the Mayagna (Sumo) Awas Tingni Community v. Nicaragua (2001)

—_, Saramaka People v. Suriname (2007)

_- Case of Kichwa Indigenous Communitiy of Sarayaku v Ecuador (2012)

—, Case of Kaliña and Lokono Peoples v Suriname (2015)

\section{Literature}

Bailey C, Cycon D and Morris M, 'Fisheries development in the Third World: The role of international agencies' (1986) 14 World Development 1269

Barros A, 'The Fetish Mechanism: A Post-Dogmatic Case Study of the Atacama Desert Peoples and the Extractive Industries' in Lennox C and Short D (eds), Handbook of Indigenous Peoples' Rights (Routledge 2016) 
Belton B and Little DC, 'Contemporary Visions for Small-Scale Aquaculture' in Chuenpagdee R (ed), World Small-Scale Fisheries: Contemporary Visions (Eburon Delft 2011)

Boyle A and Chinkin C, The Making of International Law (Oxford University Press 2007)

Chuenpagdee R and Jentoft S, 'Transforming the Governance of Small-Scale Fisheries' (2018) 17 Maritime Studies 101

Churchill RR and Lowe V, The Law of the Sea (McGoldrick D ed, 3rd edn, Manchester University Press 1999)

Citrioni $\mathrm{G}$ and Osuna KQ, 'Reparations for Indigenous Peoples in the Case of the Inter-American Court of Human Rights' in Lenzerini F (ed), Reparations for Indigenous Peoples: International and Comparative Perspectives (Oxford University Press 2008)

Claeys P and Edelman M, 'The United Nations Declaration on the rights of peasants and other people working in rural areas' (2020) 47 The Journal of Peasants Studies 1 Cotula L, 'Between Hope and Critique: Human Rights, Social Justice and Reimagining International Law from the Bottom Up' (2020) 48 Georgia Journal of International and Comparative Law 473

Cotula L and Tienhaara K, 'Reconfiguring Investment Contracts to Promote Sustainable Development' in Sauvant KP (ed), Reconfiguring Investment Contracts to Promote Sustainable Development (Oxford University Press 2013)

Desmet E, Indigenous rights entwined with nature conservation, vol 8 (Intersentia 2011)

Fodella A, 'Indigenous Peoples, the Environment, and International Jurisprudence:

Essays in Honour of Tullio Treves' in Boschiero N and others (eds), International Courts and the Development of International Law (Asser Press 2013)

Francioni F, Reparation for Indigenous Peoples: Is International Law Ready to Ensure Redress for Historical Injustices? (Oxford University Press 2008)

Fuentes A, 'Judicial Interpretation and Indigenous Peoples' Rights to Lands, Participation and Consultation. The Inter-American Court of Human Rights' Approach' (2016) 23 International Journal on Minority and Group Rights 39 Gibson D and Sumaila UR, 'Determining the degree of 'small-scaleness' using fisheries in British Columbia as an example' (2017) 86 Marine Policy 121 
Gilbert J and Doyle C, 'A New Dawn over the Land: Shedding Light on Collective Ownership and Consent' in Allen S and Xanthaki A (eds), Reflections on the UN

Declaration on the Rights of Indigenous Peoples (1st edn, Hart 2011)

Gomez N, 'Indigenous Peoples and Psychosocial Reparations: The Experience with Latin American Indigenous Communities' in Lenzerini F (ed), Reparations for Indigenous Peoples: International and Comparative Perspectives (Oxford University Press 2008)

Gover K, 'Settler-State Political Theory, 'CANZUS' and the UN Declaration on the Rights of Indigenous Peoples' (2015) 26 European Journal of International Law 345 Henriquez-Antipa LA and Carcamo F, 'Stakeholder's Multidimensional Perceptions on Policy Implementation Gaps regarding the Current Status of Chilean Small-scale Seaweed Aquaculture' (2019) 103 Marine Policy 138

Jentoft S, 'Walking the talk: implementing the international voluntary guidelines for securing sustainable smalls-scale fisheries' (2014) 13 Maritime Studies 1 Jentoft S and Eide A (eds), Poverty Mosaics: Realities and Prospects in Small-Scale Fisheries (Springer 2011)

Johnson DS, 'Category, narrative, and value in the governance of small-scale fisheries' (2006) 30 Marine Policy 747

Johnson DS, 'The Values of Small-Scale Fisheries' in Johnson DS and others (eds), Social Wellbeing and the Values of Small-scale Fisheries, vol 7 (Springer International Publishing AG 2018)

Long G, 'Underpinning commitments of the Sustainable Development Goals: indivisibility, universality, leaving no one behind' in French D and Kotzé LJ (eds), Sustainable Development Goals: Law, Theory and Implementation (Edward Elgar Publishing 2018)

McGregor D, 'Living Well with the Earth: Indigenous Rights and the Environment' in Lennox C and Short D (eds), Handbook of Indigenous Peoples' Rights (Routledge 2016) Mills DJ and others, 'Under-reported and Undervalued: Small-scale Fisheries in the Developing World' in Pomeroy R and Andrew NL (eds), Small-scale Fisheries Management: Frameworks and Approaches for the Developing World (CAB International 2011)

Mills DJ and others, 'Small-scale Fisheries in the Developing World' in Pomeroy R and Andrew NL (eds), Small-Scale Fisheries Management: Frameworks and Approaches for the Developing World (CAB International 2011) 
Molenaar EJ and Caddell R, Strengthening International Fisheries Law in an Era of Changing Oceans (Hart Publishing 2019)

Morgera E, 'Fair and Equitable Benefit-sharing at the Crossroads of the Human Right to Science and International Biodiversity Law' (2015) 4 Laws 803

_-, 'Justice, Equity and Benefit-Sharing Under the Nagoya Protocol to the Convention on Biological Diversity' (2015) 24 Italian YB Int'l L 113

__, 'The Need for an International Legal Concept of Fair and Equitable Benefit Sharing' (2016) 27 The European Journal of International Law 353

_- 'The Ecosystem Approach and the Precautionary Principle' in Morgera E and Razzaque J (eds), Encyclopedia of Environmental Law: Biodiversity and Nature Protection Law (pp. 70-80, EE 2017)

_- 'Under the radar: fair and equitable benefit-sharing and the human rights of indigenous peoples and local communities connected to natural resources' (2019) 23 The International Journal of Human Rights 1098

Morgera E and Ntona M, 'Linking small-scale fisheries to international obligations on marine technology transfer' (2018) 93 Marine Policy 295

Nakamura J, Chuenpagdee R and El Halimi M, 'Unpacking legal and policy frameworks: A step ahead for implementing the Small-Scale Fisheries Guidelines' (2021) 129 Marine Policy 1

Nakamura J and Hazin F, 'Assessing the Brazilian Federal Fisheries Law and Policy in light of the Voluntary Guidelines for Securing Sustainable Small-scale Fisheries' (2020) 113 Marine Policy 1

Papanicolopulu I, International Law and the Protection of People at Sea (Oxford University Press 2018)

Pauly D and Zeller D, 'Catch reconstructions reveal that global marine fisheries catches are higher than reported and declining' (2016) Nature Communications 7 Pavoni R, 'Mutual Supportiveness as a Principle of Interpretation and Law-Making: A Watershed for the 'WTO-and-Competing-Regimes' Debate?' (2010) 21 European Journal of International Law 649

Pentassuglia G, 'Towards a Jurisprudential Articulation of Indigenous Land Rights' (2011) 22 European Journal of International Law 165

Purcell SW and Pomeroy RS, 'Driving small-scale fisheries in developing countries' (2015) 2 Frontiers in Marine Science 1 
Redgwell C, 'International Soft Law and Globalization' in Barton B and others (eds), Regulating Energy and Natural Resources (Oxford Scholarship Online 2006)

Reimerson E, 'Between Nature and Culture: Exploring Space for Indigenous Agency in the Convention on Biological Diversity' (2013) 22 Environmental Policy

Riedel E, Giacca G and Golay C, 'The Development of Economic, Social, and Cultural Rights in International Law' in Riedel E, Giacca G and Golay C (eds), Economic, Social, and Cultural Rights in International Law: Contemporary Issues and Challenges (Oxford University Press 2014)

Rosseau Y and others, 'Defining global artisanal fisheries' (2019) 108 Marine Policy 103634

Seth S, 'Putting Knowledge in its Place: Science, Colonialism and the Postcolonial' (2009) 12 Postcolonial Studies 373

Smith H and Basurto X, 'Defining Small-Scale Fisheries and Examining the Role of Science in Shaping Perceptions of Who and What Counts: A Systematic Review' (2019) 6 Front Mar Sci 1

Song AM and Soliman A, 'Situating human rights in the context of fishing rights Contributions and contradictions' (2019) 103 Marine Policy 19

Suzuki A and Hoang V, 'Better Management Practices and their Outcomes in Shrimp Farming: Evidence from Small-Scale Shrimp Farmers in Southern Vietnam' (2018) 26 Aquaculture International 469

Tsamenyi M and Hanich Q, 'Fisheries Jurisdiction under the Law of the Sea Convention: Rights and Obligations in Maritime Zones under the Sovereignty of Coastal States' (2012) 27 The International Journal of Marine and Coastal Law 783 Uggla Y, 'What is This Thing Called 'Natural'? The Nature-culture Divide in Climate Change and Biodiversity Policy' (2009) 17 J Pol Ecology 79

Vermeylen S, Martin G and Clift R, 'Intellectual Property, Rights Systems and the Assemblage of Local Knowledge Systems' (2008) 15 International Journal of Cultural Property 201

Wanyonyi IN and others, 'Artisanal Fisher Migration Patterns in Coastal East Africa' (2016) 119 Ocean \& Coastal Management 93

\section{Reports and Other Technical Documents}

CEDAW, General recommendation No. 34 on the rights of rural women (Committee on the Elimination of Discrimination against Women, CEDAW/C/GC/34, 4 March, 2016) 
De Schutter O, Report of the UN Special Rapporteur on the right to food. Promotion and protection of human rights: human rights questions, including alternative approaches for improving the effective enjoyment of human rights and fundamental freedoms (Doc A/67/268 of 8 August 2012, 2012)

ECOWAS, Directive on the Harmonization of Guiding Principles and Policies in the mining Sector (C/DIR3/05/09, 2009)

FAO, The ecosystem approach to fisheries (FAO Technical Guidelines for Responsible Fisheries No 4, Suppl 2 Rome, FAO 2003112 p, 2003)

_- Report of the Global Conference on Small-Scale Fisheries Securing Sustainable Small-scale Fisheries: bringing together responsible fisheries and social development (2008)

— January-4 February 2011 FIPI/R973, 2011)

_- Voluntary Guidelines on the Responsible Governance of Tenure of land, fisheries and forests in the Context of National Food Security (Adopted at the 38th (Special) Session of the Committee on World Food Security, in Rome, on 22 May 2012) (2012) —, Chairperson's Report of the Technical Consultation on International Guidelines for Securing Sustainable Small-Scale Fisheries (Thirty-first Session of the FAO Committee on Fisheries, 9-13 June 2014, COFI/2014/Inf10, 2014)

— 2014 FIPI/R1101/2015, 2014)

— - Securing Sustainable Small-Scale Fisheries: Update on the Development of the Voluntary Guidelines for Securing Sustainable Small-Scale Fisheries in the Context of Food Security and Poverty Eradication (SSF Guidelines) (FAO 2014)

_- Securing Sustainable Small-Scale Fisheries: Towards Implementation of the Voluntary Guidelines for Securing Sustainable Small-Scale Fisheries in the Context of Food Security and Poverty Eradication (SSF Guidelines) (COFI 32nd Session, Doc COFI 2016/7, April, 2016)

__, Small-Scale and Artisanal Fisheries Governance (COFI 33rd Session, Doc COFI/2018/7, March, 2018)

— - Update on Progress to Develop the Global Strategic Framework in Support of the Implementation of the Voluntary Guidelines for Securing Small-Scale Fisheries in the Context of Food Security and Poverty Eradication (SSF-GSF) (COFI 33rd Session, COFI/2018/SBD23, July, 2018) 
_- Legislating for Sustainable Small-Scale Fisheries - A guide and considerations for implementing aspects of the Voluntary Guidelines for Securing Sustainable SmallScale Fisheries in the Context of Food Security and Poverty Eradication in national legislation (FAO, 2020)

—, Proceedings of the International Symposium on Fisheries Sustainability: strengthening the science-policy nexus (FAO Headquarters, 18-21 November 2019 FAO Fisheries and Aquaculture Proceedings No 65 Rome, 2020)

FAO UU, Guidelines on Free, Prior and Informed Consent (UN-REDD Programme, 2013)

Fischer J and others (eds), Fishers' knowledge and the ecosystem approach to fisheries: applications, experiences and lessons in Latin America (FAO Fisheries and Aquaculture Technical Paper No. 591. Rome, FAO. 278 pp. 2015) FISHINMED, Small-Scale Fisheries Multifunctionality Best Practices (Report prepared under the ENPI CBC Mediterranean Sea Basin Programme 2007-2013, 2013)

Funge-Smith S, Towards Statistical Definition of Small-Scale Fisheries: A matrix scoring approach to characterization of the scale of fishing units (Working paper CWPIS/2019/11 Twentyseventh Meeting of the Fisheries Subject Group, Coordinating Working Party on Fishery Statistics, Rome, 15-18 May 2019, 2019) ILA, Final Report on the Rights of Indigenous Peoples (International Law Association, SOFIA Conference) (2012)

Kurien J, Small-scale Fisheries in the Context of Globalisation (1998)

UNGA, Resolution 61/105 Sustainable fisheries, including through the 1995 Agreement for the Implementation of the Provisions of the United Nations Convention on the Law of the Sea of 10 December 1982 relating to the Conservation and Management of Straddling Fish Stocks and Highly Migratory Fish Stocks, and related instruments (UNGA 61st Session, 8 December, 2006)

—, Report of the Third Committee, 55th Plenary Meeting (17 December 2018 UN Doc A/73/PV55, 2018)

UNHRC, Resolution 21/19 of 11 October 2012 on the Promotion and Protection of the Human Rights of Peasants and Other People Working in Rural Areas (Adopted at the 21st Session of the Human Rights Council, A/HRC/RES/21/19, 2012) 
— - Report by Special Rapporteur John H. Knox on the issue of human rights obligations relating to the enjoyment of a safe, clean, healthy and sustainable environment (UN Doc A/HRC/37/59, 2018)

— - Report of the Human Rights Council on its Thirty-Ninth Session, 23 November 2018, UN Doc. A/HRC/39/2 (2018) 191p. (2018)

— - Report of the Special Rapporteur on the issue of human rights obligations relating to the enjoyment of a safe, clean, healthy and sustainable environment (UN Doc $\mathrm{A} / \mathrm{HRC} / 37 / 58,2018)$

Yeshanew S, Franz N and Westlund L, FAO Fisheries and Aquaculture Proceedings. No. 53. Exploring the human rights-based approach in the context of the implementation and monitoring of the SSF Guidelines. (2016)

\section{Internet Sources}

FAO, Enhancing the contribution of small-scale fisheries to food security and sustainable livelihoods

—, Global Strategic Framework in support of the implementation of the Voluntary Guidelines for Securing Sustainable Small-Scale Fisheries in the context of food security and poverty eradication

Morgera E, 'A reflection on benefit-sharing as a Framework Principle on Human Rights and the Environment proposed by UN Special Rapporteur John Knox (Part I)' (BeneLex Blog, 8 April 2018) <https://benelexblog.wordpress.com/2018/04/08/areflection-on-benefit-sharing-as-a-framework-principle-on-human-rights-and-theenvironment-proposed-by-un-special-rapporteur-john-knox-part-i/> accessed 06 October 2020

UNHRC, 'Current Membership of the Human Rights Council for the 14th cycle, 1 January - 31 December 2020' (2020)

$<$ https://www.ohchr.org/en/hrbodies/hrc/pages/currentmembers.aspx $>$ accessed 30 April 2021

\section{National Legislation}

Aquatic and Biological Resources Law (New Fishing Act) No. 6-A/2004 (Angola, Promulgated on 3 September 2004, published in the Republic Gazette No. 81, Series I, Supplement on 8 October 2004)

Ghana. Fisheries Act No. 625/2002 